\title{
Analisis Pembiayaan Mudharabah Bank Pembiayaan Rakyat Syariah Terhadap Nonperforming Financing di Indonesia Tahun 2015-2020
}

\author{
Andiman $^{1}$, Agus Widardjono ${ }^{2}$ \\ Universitas Islam Indonesia \\ Email : andhyman2796@gmail.com ${ }^{1}$, agus.widarjono@uii.ac.id ${ }^{2}$
}

\begin{abstract}
This study aims to analyze the effect of the type of financing on the Non-Performing Financing (NPF) of Islamic People's Financing Banks in Indonesia for the 2015-2019 period. The research method used is panel data regression with the Fixed Effect model as the recommended model based on the results of the model selection test. The results showed that the Log Mudharabah variable had a negative effect on the Non Performing Financing of Islamic Rural Banks. Mudharabah Log, Non Performing Financing

Keywords : Log Mudharabah, Non Performing Financing

Abstrak : Penelitian ini bertujuan untuk menganalisis pengaruh jenis pembiayaan terhadap Non Performing Financing (NPF) Bank Pembiayaa Rakyat Syariah di Indonesia periode 20152019. Metode penelitian yang digunakan adalah regresi data panel dengan model Fixed Effect sebagai model yang direkomendasikan berdasarkan hasil uji pemilihan model. Hasil penelitian ditemukan bahwa variabel Log Mudharabah, berpengaruh negatif terhadap Non Performing Financing Bank Pembiayaan Rakyat Syariah. Log.

Kata Kunci : : Mudharabah, Non Performing Financing
\end{abstract}

\section{A. Pendahuluan}

Perkembangan keuangan Islam di dunia saat ini sedang hangat-hangatnya tidak terkecuali di Indonesia. Sejak awal kemunculan Bank Syariah terus mengalami pertumbuhan yang flukstuatif setiap tahunya, baik dari segi Asset, jumlah pembiayaan yang disalurkan (PYD) maupun pertumbuhan dana pihak ke tiga.

Perkembangan perbankan syariah di Indonesia juga nampak dari meningkatnya jumlah industri perbankan syariah, hingga Maret 2020 total industri perbankan syariah berjumlah 197 yang terdiri dari Bank Umum Syariah berjumlah 14 Bank, Unit Usaha Syariah berjumlah 20 Unit, Bank Pembiayaan Rakyat Syariah berjumlah 163 unit. Dari total jumlah industri perbankan sebanyak 197, terdapat 2.929 jumlah kantor industri perbankan syariah di seluruh Indonesia ${ }^{1}$.

Perbankan syariah berbeda dengan perbankan konvensional. Sebab, perbankan syariah merupakan Bank yang menjalankan kegiatan usahanya berdasarkan prinsip Syariah. Sedangkan bank konvensional adalah bank yang menjalankan kegiatan usahanya secara konvensional. yang menurut jenisnya teridir dari Bank Umum Konvensional dan Bank Perkreditan Rakyat ${ }^{2}$. Karena perbankan Syariah beroperasi berdasarkan prinsip Syariah maka dalam praktik Bank Syraiah harus memberikan layanan dan produk sesuai dengan praktek dan hukum agama Islam ${ }^{3}$, dan larangan penggunaan sistem bunga dalam operasional Bank Syariah $^{4}$. serta harus menjunjung tinggi nilai-nilai keadilan, serta prinsip transaksi seperti,

\footnotetext{
${ }^{1}$ Snapshot Perbankan Syariah Indonesia 2020, n.d. Penulisan Foot Note Disesuaikan

2 "Undang-Undang Nomor 21 Tahun 2008 Tentang Perbankan Syariah," accessed November 27, 2020, https://www.ojk.go.id/waspada-investasi/id/regulasi/Pages/Undang-Undang-Nomor-21-Tahun-2008-TentangPerbankan-Syariah.aspx.

${ }^{3}$ Martin Čihák and Heiko Hesse, "Islamic Banks and Financial Stability: An Empirical Analysis," Journal of Financial Services Research 38, no. 2 (2010): 95-113.

${ }^{4}$ Ghada Ben Zeineb and Sami Mensi, "Does the PLS Paradigm Spur the Islamic Banks Vs Conventional Banks Soundness: Case of the Global Financial Crisis," Journal of Economics and Development Studies 2, no. 3 (2014): 177-192.
} 
bagi hasil, keadilan dalam bertransaksi, investasi yang beretika, mengedepankan nilai-nilai kebersamaan dan persaudaraan dalam berproduksi, serta menghindari segala bentuk transaksi yang mengandung unsur spekulatif. Salahsatu aspek yang paling menonjol yang menjadi pembeda antara perbankan Islam dan Konvensional adalah penggunaan kontrak Profit-Loss Sharing (PLS) pada perbankan syariah. Kontrak PLS ini diwakili oleh kontrak Mudharabah dan Musyarakah ${ }^{5}$. Yang dimaksud dengan pembiayaan dengan kontrak Profil-Loss Sharing adalah adalah kontrak di mana keuntungan dibagi atas pemilik dana (Shahibul Mal) dan pengelola dana (Mudharib) dengan rasio yang telah ditentukan terlebih dahulu ${ }^{6}$.

Praktek perbankan syariah di dunia termasuk di Indonesia kontrak perbankan syariah masih di dominasi oleh kontrak Murabaha, sebab kontrak PLS yang diwakili oleh Mudharabah dan Musyarakah dinilai lebih beresiko ${ }^{7}$. Untuk Indonesia berikut jenis penggunaan akad pada industri perbankan yaitu, Istisna' 0.06\%, Qardh 3.06\%, Ijarah 2.74\%, Mudharabah 3.75\%, Musyarakah 43.93\%, Murabahah $45.65 \%$, akad lainya $0.26 \%$.

Tantangan yang dihadapi perbankan syariah selain masalah Image bahwa Bank Islam sama saja dengan Bank Konvensional juga menghadapi pangsa basar yang masih stagnan pada angka 5\%. dimana 5.99\% pada Maret 2020, kondisi ini tidak jauh berbeda pada tahuntahun sebelumnya yaitu 5.95 pada Juni 2019. Tingginya kredit macet (Non Performing Financing) pada Bank Syariah, yang berada diatas 5\% melebihi batas maksimal yang telah ditetapkan oleh Bank Indonesia. Januari 2021 NPF BPRS sebesar 7.70\% ${ }^{9}$

Pembiayaan dengan kontrak PLS yang merupakan ciri khas dari Perbankan Syariah ternyata tidak banyak diminati, disebabkan oleh resiko yang mengikutinya. Resiko potensi terjadinya kredit macet pada perbankan membuat stackholder sangat jarang menggunakan kontrak PLS. Tidak hanya potensi resiko, tetapi juga peluang terjadinya moral Hazard sangat besar didalam kontrak PLS.

Masih sedikit penelitian yang menganalisis secara langsung dampak kontrak PLS yang diwakili oleh akad Mudharabah terhadap terjadinya kredit macet pada Bank Syariah. Oleh karena itu penulis tertarik untuk meneliti tentang "Pengaruh Pembiayaan Mudharabah Terhadap Non Performing Financing Bank Pembiayaan Rakyat Syariah di Indonesia".

Berdasarkan latarbelakang diatas maka peneliti kali ini akan menganalisis bagaimana pengaruh pembiayaan dengan kontrak PLS yang diwakili oleh Mudharabah, Financial to Deposit Ratio, Biaya Operational Terhadap Pendapatan Operational, Asset dan pertumbuhan ekonomi regional (PDRB) terhadap kredit macet Bank Pembiayaan Rakyat Syariah di Indonesia.

\footnotetext{
${ }^{5}$ Humayon a Dar and John R Presley, "Lack of Profit Loss Sharing in Islamic Banking : Management and Control Imbalances," International Journal of Islamic Financial Services 2, no. 00 (2000): 9-12; Zeyneb Hafsa Orhan Astrom, "Credit Risk Management Pertaining to Profit and Loss Sharing Instruments in Islamic Banking,” Journal of Financial Reporting and Accounting 11, no. 1 (2013): 80-91.

6 Abbas Mirakhor and Iqbal Zaidi, "Profit-and-Loss Sharing Contracts in Islamic Finance," Handbook of Islamic Banking m (2007): 49-63.

${ }^{7}$ Noraini Mohd Ariffin, Simon Archer, and Rifaat Ahmed Abdel Karim, "Risks in Islamic Banks: Evidence from Empirical Research," Journal of Banking Regulation 10, no. 2 (2009): 153-163; Awatef Louhichi and Younes Boujelbene, "Credit Risk, Managerial Behaviour and Macroeconomic Equilibrium within Dual Banking Systems: Interest-Free vs. Interest-Based Banking Industries," Research in International Business and Finance 38 (2016): 104-121; Hafsa Orhan Astrom, "Credit Risk Management Pertaining to Profit and Loss Sharing Instruments in Islamic Banking."

8 "Statistik Perbankan Syariah," accessed April 11, 2021, https://www.ojk.go.id/id/kanal/syariah/data-danstatistik/statistik-perbankan-syariah/default.aspx.

${ }^{9}$ Ibid.
} 
Selanjutnya dilakukan analisis untuk memastikan apakah benar jika kontrak PLS berpengaruh signifikan terhadap terjadinya Non Performing Financing pada Bank Pembiayaan Rakyat Syariah. Analisis dalam penelitian ini dilakukan dengan menggunakan metode Regresi Data Panel. Data panel merupakan gabungan data time series dan crossection.Regresi data penel dapat dilakukan dengan menggunakan tiga model regresi yaitu koefisien tetap antar waktu (Common Effect), slope konstan tetapi intersep berbeda antara individu (Fixed Effect), dan regresi dengan model Random Effect.

Produk pembiayaan dalam penelitian ini adalah pembiayaan dengan konsep Profit-Loss Sharing yaitu kontrak Mudharabah. Dalam Fiqih muamalah termonologi Mudharabah merupakan suatu bentuk perjanjian dalam melakukan kongsi untuk mendapatkan keuntungan dengan modal dari salahsatu pihak dan usaha (kerja) dilakukan oleh pihak lain ${ }^{10}$. Variabel dependen dalam penelitian ini yaitu, Non Performing-Financing (NPF) merupakan rasio keuangan yang digunakan untuk mengukur risiko usaha perbanakn yang menunjukan bersarnya resiko pembiayaan bermasalah yang ada pada sautu Bank ${ }^{11}$.

Telah banyak penelitian yang dilakukan untuk menganalisis variabel Mudharabah, Musyarakah, Murabaha, FDR, BOPO, Asset PDRB dan Non Performing Financing, meskipun kadang dalam komposisi variabel yang berbeda-beda.

Penelitian yang dilakukan oleh Warninda:2919 yang berjudul "Do Murabahah And Musyarakahfinancing Impact Islamic Bank Credit Risk Differently". Dari hasil penelitian tersebut ditemukan bahwa bahwa Mudharabah tidak lebih berisiko dibandingkan Musyarakah. Selain itu Mudharabah tidak menunjukkan dampak non-linear sementara pembiayaan Musyarakah menunjukkan pengaruh terbalik (non-linear) pada risiko kredit bank syariah $^{12}$. Chasanah et.al:2012 Hasil penelitian menunjukkan bahwa pertumbuhan GDP dan kurs nilai tukar rupiah terhadap Dolar mempunyai nilai pengaruh positif terhadap Non Perfirming Financing namun tidak signifikan, Inflasi mempunyai pengaruh negatif terhadap Non Performing Financing dan signifikan. Dan rasio return profit loss sharing terhadap return total pembiyaan (RR) mempunyai pengaruh negatif terhadap Non Performing Financing tetapi tidak signifikan, rasio alokasi pembiayaan Murabahah terhadap alokasi pembiayaan profit loss sharing berpengaruh negatif dan signifikan terhadap terhadap Non Performing Financing $^{13}$. Popita:2013 hasil penelitian disimpulkan bahwa pertumbuhan GDP ril dan FDR berpengaruh tidak signifikan terhadap NPF. Inflasi, SWBI, RR berpengaruh negatif dan tidak signifikan terhadap NPF. Sedangkan total aset mempunyai pengaruh negatif signifikan terhadap $\mathrm{NPF}^{14}$. Osman tahun 2013 hasil penelitian menunjukkan bahwa pembiayaan Mudharabah tidak berpengaruh signifikan terhadap Non Performing Financing (NPF) dan pembiayaan Musyarakah juga tidak berpengaruh signifikan terhadap Non Performing Financing (NPF) pada bank Syariah di Indonesia ${ }^{15}$. Putra tahun 2019 hasil penelitian menunjukkan bahwa pembiayaan Mudharabah memiliki pengaruh positif terhadap NPF,

${ }^{10}$ Tim OJK, "Standar Produk Mudharabah" (2017): 1-292.

11 "Statistik Perbankan Syariah."

12 Titi Dewi Warninda, Irwan Adi Ekaputra, and Rofikoh Rokhim, "Do Mudarabah and Musharakah Financing Impact Islamic Bank Credit Risk Differently?," Research in International Business and Finance 49, no. September 2017 (2019): 166-175.

${ }^{13}$ Mutamimah and siti nur zaidah Chasanah, “Analisis Eksternal Dan Internal Dalam Menentukan," jurnal bisnis dan ekonomi (JBE) 19, no. 1 (2012): 49-64.

${ }^{14}$ Mares Suci Ana Popita, "Analisis Penyebab Terjadinya Non Performing Financing Pada Bank Umum Syariah Di Indonesia,” Accounting Analysis Journal 2, no. 4 (2013): 404-412.

${ }^{15}$ Hamdan Bin Osman, "Pengaruh Pembiayaan Mudharabah Dan Musyarakah Terhadap Non Performing Financing (NPF)," Artikel Ilmiah (2013). 
pembiayaan Murabahah memiliki pengaruh negatif terhadap NPF, sedangkan pembiayaan Musyarakah dan Qardul Hasan tidak berpengaruh terhadap NPF ${ }^{16}$. Akbar:2016 hasil penelitian menunjukkan jika inflasi tidak berpengaruh terhadap Nonperforming Financing, pertumbuhan ekonomi (GDP), Capital Adequacy Ratio (CAR) Financial To Deposit Ratio (FDR) berpengaruh negatif terhadap Nonperforming Financing. Yang artinya jika terjadi pertumbuhan ekonomi, CAR, FDR sebesar 1 satuan maka akan menurunkan Nonperforming Financing sebesar satu satuan ${ }^{17}$. Efendi tahun 2017, hasil penelitian variabel yang berpengaruh negatif signifikan terhadap Non Performing Financing adalah rasio pendapatan pembiayaan syariah (RR), retirn on asset (ROA), inflatsi, capital adequacy ratio (CAR), ukuran Bank, pertumbuhan ekonomi (GDP), sedangkan biaya operasional terhadap pendapatan operasional (BOPO) berpengaruh positif dan signifikan ${ }^{18}$.

\section{B. Metodologi}

Jenis penelitian ini adalah penelitian kuantitatif dengan objek penelitian yaitu BPRS di seluruh Indonesia yang berjumlah 165 BPRS. Jumlah BPRS tersebut juga menjadi populasi dalam penelitian ini. Dari jumlah populasi sebanyak 165 diperoleh sampel berjumlah 116 BPRS dengan menggunakan rumus Solvin. Teknik sampling dalam penelitian ini menggunakan Purposive Random Sampling dimana dalam pengambilan sampel peneliti menentukan kriteria tertentu yang akan menjadi sampel. Kriteria yang ditetapkan adalah BPRS secara aktif menguppdate laporan keuanganya setiap periode yang telah ditentukan oleh OJK, memiliki laporan keuangan yang lengkap pada halaman web OJK (www.ojk.go.id), BPRS mempunyai pembiayaan yang menjadi variable dalam penelitian ini yaitu Mudharabah, Musyarakah dan Murabahah.

Data dalam penelitian ini merupakan data sekunder yang diperoleh dari laporan keuangan BPRS yang diakses melalui website OJK. Data dalam penelitian ini dalam analisis ekonometrika disebut data panel (poled data) yang merupakan gabungan antara data runtut waktu (time series) dan data antar waktu dan tempat (cross section) ${ }^{19}$. Periode data dalam penelitian ini yaitu 5 tahun (2015-2019) yang dibagi dalam bentuk kuartal. Jumlah BPRS yang dianalisis dalam penelitian ini berjumlah 86 yang memenuhi kriteria purposive random sampling. Data dalam penelitian ini dianalisis menggunakan metode regresi data panel. Dalam regresi data panel terdapat beberapa metode analisis yang dapat digunakan sesuai dengan penelitian. Berikut beberapa model estimasi dalam Regresi data Panel.

\section{Common effect}

Metode koefisien tepat antar waktu dan inividu (common effect) merupakan salahsatu metode analisis regresi data panel yang paling sederhana. Hal ini dikarenakan dalam model ini hanya mengkombinasikan data time series dan crossection, tanpa melihat perbedaan antar waktu dan individu, dalam model Common Effect juga diasumsikan jika perilaku data anatar

\footnotetext{
${ }^{16}$ Rosyid Nur Anggara Putra, "Karakteristik Pembiayaan Dan Non Performing Finance Perbankan Syariah 2015-2018,” MALIA: Journal of Islamic Banking and Finance 3, no. 1 (2019): 1.

${ }^{17}$ Dinul Alfian Akbar, "Inflasi, Gross Domesctic Product (Gdp), Capital Adequacy Ratio (Car), Dan Finance To Deposit Ratio (Fdr) Terhadap Non Performing Financing (Npf) Pada Bank Umum Syariah Di Indonesia," I-Economics 2, no. 2 (2016): 19-37.

${ }^{18}$ Jaenal Effendi, Usy Thiarany, and Tita Nursyamsiah, "Factors Influencing Non-Performing Financing (NPF) at Sharia Banking," Walisongo: Jurnal Penelitian Sosial Keagamaan 25, no. 1 (2017): 109.

19 "Ekonometrika Pengantar Dan Aplikasinya Edisi 5 - Agus Widarjono | Shopee Indonesia," accessed April 11, 2021, https://shopee.co.id/Ekonometrika-Pengantar-Dan-Aplikasinya-Edisi-5-Agus-Widarjonoi.3813657.1658609173.
} 
perusahaan sama dalam berbagai kurun waktu ${ }^{20}$. Model regresi Common Effect dalam penelitian ini yaitu:

\section{Fixed effect}

$$
\begin{aligned}
& \ln Y_{i t}=\beta_{0}+\beta_{1} \ln X_{1 i t}+\beta_{2} \ln X_{2 i t}+\ldots \ldots . . \beta_{n} \ln X_{n i t}+e_{i t} \\
& \ln N P F_{i t}=\beta_{0}+\beta_{1} \ln M u d h a r a b a h_{1 i t}++e_{i t}
\end{aligned}
$$

Berbeda dengan model Common Effect yang mengasumsikan jika intersep maupun slope adalah sama baik antara waktu meupun antara individu. Fixed Effect justru mengasumsikan jika intersep adalah berbeda antara perusahaan sedangkan slope-nya sama santara perusahaan $^{21}$. Model regresi panel dalam bentuk logaritma natural dengan Fixed Effect yang mengasumsikan adanya perbedaan antara intersep yaitu:

$$
\ln Y_{i t}=\beta_{0 i}+\beta_{1} \ln X_{1 i t}+\beta_{2} \ln X_{2 i t}+\ldots \ldots . . \beta_{n} \ln X_{n i t}+e_{i t}
$$

Tampak dalam model regresi Fixed Effect di atas ditambahkan enskrip $i$ pada intersep untuk menunjukkan jika interset antara BPRS mungkin berbeda.

Untuk menangkap adanya perbedaan intersep antara BPRS maka teknik model fixed effect mengestimasi data panel dengan menggunakan variabel dummy. Teknik Last Squares Dimmy Variables (LSDV) adalah teknik estimasi Fixed Effect Dengan menggunakan variabel dummy untuk menjelaskan perbedaan intersep. Model regresi fixed effect dalam penelitian ini dengan teknik variabel dummy dapat ditulis:

$$
\operatorname{lnNPF}_{i t}=\beta_{0}+\beta_{1} \operatorname{lnMudharabah}{ }_{1 i t}+\beta_{8} \sum \mathrm{D}_{\mathrm{it}}+e_{i t}
$$

\section{Random effect}

Dalam model Random Effect diasumsikan bahwa setiap perusahaan memiliki intersep yang berbeda. Meskipun demikian diasumkikan pula jika intersep adalah variabel random stokastik $^{22}$. Model ini sesuai juga dengan penelitian ini sebab sampe diambil secara random yang merupakan wakil dari populasi.

$$
\ln Y_{i t}=\beta_{0 i}+\beta_{1} \ln X_{1 i t}+\beta_{2} \ln X_{2 i t}+\ldots \ldots . . \beta_{n} \ln X_{n i t}+e_{i t}
$$

Model sebelumnya (fixed effect) $\beta_{0 i}$ bersifat tetap (non stokastik), namun dalam moel Random Effect $\beta_{0 i}$ tidak lagi tetap tetapi bersifat random. Sehingga $\beta_{0 i}$ dapat diekspresikan sebagai berikut:

$$
\beta_{0 i}=\hat{\beta}_{0}+\mu_{\mathrm{i}} \text { di mana } i=1 \ldots n
$$

keterangan:

Dengan mensubtitusikan persamaan Fixed Effect ke persamaan (1) maka diperoleh persamaan regresi Random Effect sebagai berikut:

$$
\begin{aligned}
& \ln Y_{i t}=\beta_{0}+\mu_{\mathrm{i}}+\beta_{1} \ln \text { Mudharabah } \\
& \ln Y_{i t}+e_{i t} \\
& \ln \beta_{0}+\beta_{1} \ln \text { Mudharabah } \\
& \ln Y_{i t}=\beta_{0}+\beta_{1} \ln \text { Mudharabah } \\
& \text { dit } \left.+\mu_{\mathrm{i}}\right) \\
& \text { di mana }: \mathrm{v}_{i t}=\boldsymbol{D}_{i t}+\mu_{\mathrm{it}}
\end{aligned}
$$

Persamaan dua (2) merupakan persamaan model Random Effect.

Langkah selanjutnya dalam regresi data panel adalah memilih metode mana yang paling tepat diantara ketiga model diatas, untuk digunakan dalam penelitian. Terdapat tiga teknik pemilihan regresi data panel, yaitu pertama, Uji Chow (F-statistik). Uji F statistik merupakan uji perbedaan dua regresi sebagaimana uji Chow. Uji F digunakan untuk mengetahui apakah

\footnotetext{
${ }^{20}$ Ibid.

${ }^{21}$ Ibid

22 Ibid
} 
teknik regresi data panel dengan fixed effect lebih baik dari model regresi data panel tanpa variabel dummy (Common Effect) dengan melihat sum off squared residuals (RRS) ${ }^{23}$. Kedua, Uji Langgrange multiplier (LM-Test). Uji LM digunakan untuk mengetahui apakah model random effect lebih baik dari model metode OLS ${ }^{24}$. Ketiga, Uji Husman. Uji Hausman yang dikembangkan oleh Hausman 1978 adalah uji statistik dengan tujuan untuk memilih apakah menggunakan model Fixed Effect atau Random Effect, dalam ${ }^{25}$. Uji Hausman dapat dijelaskan dengan menggunakan covarian matrix dari perbedaan vekto, $\left[\overline{\beta_{O}}-\overline{\beta_{G}}\right]$. Statistik uji Hausman mengikuti distribusi statistik Chi Square dengan degree off freadom sebanyak $k$ di mana $k$ adalah variabel independen.

\section{Hasil dan Pembahasan}

\section{Estimasi model data penel}

a. Common effect

Hasil regresi dengan model common effect dalam penelitian ini dapat dilihat sebagai berikut:

Tabel 1 Hasil Estimasi Model Common Effect

\begin{tabular}{|c|r|r|r|r|}
\hline Variable & Coefficient & Std. Error & t-Statistic & Prob. \\
\hline C & 55.35199 & 6.588855 & 8.400851 & 0.0000 \\
\hline Log mudharabah & -0.195524 & 0.190630 & -1.025671 & 0.3055 \\
\hline Sumber: Hasil Olahan Eviews
\end{tabular}

\section{b. Fixed effect}

Hasil estimasi data panel dengan metode fixed effect.

Tabel 2 Hasil Estimasi Model Fixed Effect

\begin{tabular}{|c|r|r|r|r|}
\hline Variable & Coefficient & Std. Error & t-Statistic & Prob. \\
\hline C & 221.9166 & 13.64218 & 16.26695 & 0.0000 \\
\hline Log Mudharabah & -1.082479 & 0.256659 & -4.217579 & 0.0000 \\
\hline
\end{tabular}

Sumber: Hasil Olahan Eviews

\section{c. Random effect}

Berikut hasil estimasi dengan model random effect.

Tabel 3 Hasil Estimasi Model Random Effect

\begin{tabular}{|c|r|r|r|r|}
\hline Variable & Coefficient & Std. Error & t-Statistic & Prob. \\
\hline C & 133.1662 & 8.908149 & 14.94881 & 0.0000 \\
\hline Log Mudharabah & -0.538045 & 0.219697 & -2.449036 & 0.0146 \\
\hline
\end{tabular}

\section{Uji Chow (F-statistik)}

Uji F adalah uji yang digunakan untuk memilih antara metode OLS/Common effect atau fixed effect. Hipotesis dalam pengujian ini adalah:

$\mathbf{H}_{\mathbf{0}}$ : memilih model common effect

${ }^{23}$ Ibid.

${ }^{24}$ T. S. Breusch and A. R. Pagan, "The Lagrange Multiplier Test and Its Applications to Model Specification in Econometrics," The Review of Economic Studies 47, no. 1 (1980): 239.

25 Masayuki Hirukawa, "Specification Testing" 46, no. 6 (2018): 73-101. 
$\mathbf{H}_{\mathbf{a}}$ : memilih model fixed effect

Dalam menentukan model yang paling tepat untuk digunakan adalah dengan melihat nilai probabilitasnya. Apabila nilai signifikansinya $<5 \%$ maka model estimasi yang akan digunakan adalah fixed effect. Akan tetapi jika nilai signifikansinya $>5 \%$ maka model estimasi yang akan digunakan adalah common effect. Berikut hasil regresi dengan uji F.

Tabel 4 Hasil Estimasi F-statistik

\begin{tabular}{|l|r|r|c|}
\hline Effects Test & Statistic & d.f. & Prob. \\
\hline Cross-section F & 14.056391 & $(48,527)$ & 0.0000 \\
\hline Cross-section Chi-square & 480.565491 & 48 & 0.0000 \\
\hline
\end{tabular}

Sumber: Hasil Olahan Eviews

Berdasarkan hasil pengujian antara model common effect dan fixed effect diperoleh nilai F-statistik sebesar 14.056391 probabilitas cross section chi-square sebesar 0.0000. nilai probabilitas ( $p$-value) lebih kecil dari $\alpha 5 \%(0,0000<5 \%)$. Maka dengan ini menolak $\mathrm{H}_{0}$ dan menerima $\mathrm{H}_{\mathrm{a}}$. Sehingga model yang paling tepat untuk digunakan adalah fixed effect. Hal ini didukung dengan menggunakan hasil perhitungan F-hitung 14.056391 dan F-kritis, dengan Numerator $\mathrm{N}-\mathrm{k}=82$ dan denumerator $=7$ diperoleh nilai F-hitung sebesar 2.12. dapat dilihat jika F-hitung > F-kritis Maka dengan ini menolak $\mathrm{H}_{0}$ dan menerima $\mathrm{H}_{\mathrm{a}}$. sehingga model yang paling tepat untuk digunakan adalah fixed effect.

\section{Uji Langrange Multiplier}

Uji Lagrange Multiplier atau kita sering kenal dengan uji LM adalah uji yang dilakukan untuk memilih model yang paling tepat untuk memilih antara model Common Effect atau Random Effect. Hipotesis dalam pengujian ini adalah:

$\mathbf{H}_{\mathbf{0}}$ : model common effect lebih baik

$\mathbf{H}_{\mathbf{a}}$ : model random effect lebih baik

Berikut hasil regresi dengan uji Lagrange Multiplier (uji LM):

Tabel 5 Hasil Uji LM Test

\begin{tabular}{|l|l|l|l|}
\hline Lagrange Multiplier Tests for Random Effects \\
\hline & Test Hypothesis & \multicolumn{2}{l|}{} \\
\hline & Cross-section & Time & Both \\
\hline Breusch-Pagan & 303.7247 & 5.191570 & 308.9162 \\
\hline & $(0.0000)$ & $(0.0227)$ & $(0.0000)$ \\
\hline
\end{tabular}

Sumber: Hasil Olahan Eviews

Berdasarkah hasil regresi pemilihan model anatara Common Effect atau Random Effect dapat dilihat, nilai p-value pada Breusch-Pagan sebesar 0.0000. nilai p-value ini lebih kecil dari $\alpha$ 5\%. Maka model uji Langrange Multiplier, menunjukkan jika menolak $\mathrm{H}_{0}$ dan menerima $\mathrm{H}_{\mathrm{a}}$ yang bermakna model random effect adalah model yang dipilih untuk mengestimasi model regresi data panel. Hal ini juga sesuai dengan nilai statistik BreuschPagan sebesar 303.7247. dengan $\mathrm{df}=82$ dan $\alpha=5 \%$ nilai Chi-Square sebesar 62,1323 . Nilai Breusch-Pagan > Chi-Square maka menolak $\mathrm{H}_{0}$ dan menerima $\mathrm{H}_{\mathrm{a}}$.

\section{Uji Husman}

Pengujian Husman digunakan untuk memilih model yang plaing tepat untuk digunakan antara estimasi fixed effect atau random effect. Hipotesis dalam pengujian ini adalah:

$\mathbf{H}_{\mathbf{0}}$ : memilih menggunakan model random effect 
$\mathbf{H}_{\mathbf{a}}$ : memilih menggunakan model fixed effect

Apabila nilai probabilitasnya signifikan pada $\alpha$ tertentu $(1 \%, 5 \%$, dan $10 \%)$ maka model yang digunakan adalah fixed effect. Sebaliknya jika nilai probabilitasnya tidak signifikan pada $\alpha(1 \%, 5 \%$, dan $10 \%)$ maka model yang digunakan adalah random effect. Berikut hasil estimasi dengan uji Husman:

Tabel 6 Hasil Uji Husman Test

\begin{tabular}{|l|l|l|l|}
\hline \multicolumn{3}{|l|}{ Correlated Random Effects - Hausman Test } & \\
\hline & $\begin{array}{l}\text { Chi-Sq. } \\
\text { Statistic }\end{array}$ & Chi-Sq. d.f. & Prob. \\
\hline Test Summary & 137.902992 & 7 & 0.0000 \\
\hline Cross-section random & & & \\
\hline
\end{tabular}

Sumber : hasil olah eviews

Berdasarkan tabel uji Husman diatas diperoleh nilai chi-square sebesar 137.902992 dengan probabilitas ( $p$-value) sebesar 0.0000. sedangkan nilai kritis chisquare dengan $\mathrm{df}=82$ pada $\alpha 5 \%$ sebesar 62,1323. Berdasarkan nilai chi-square dan probabilitas, kita menolak $\mathrm{H}_{0}$ dan menerima $\mathrm{H}_{\mathrm{a}}$ model yang paling tepat adalah Fixed effect.

\section{Analisis Pembiayaan Mudharabah Bank Pembiayaan Rakyat Syariah Terhadap Nonperforming Financing di Indonesia}

a. Uji Koefisien Determinasi R-square $\left(\mathbf{R}^{\mathbf{2}}\right)$

Pengujian koefisien determinasi $\left(\mathrm{R}^{2}\right)$ dilakukan untuk mengukur persentase dari variasi total variabel dependen mampu dijelaskan oleh model regresi. Widardjono (2013) menjelaskan konsep koefisien determinasi $\left(\mathrm{R}^{2}\right)$ dilakukan untuk mengukur seberapa baik garis regresi cocok dengan datanya atau mengukur total persentase $Y$ (variabel independen) yang dijelaskan oleh garis regresi.

Berdasarkan hasil estimasi model Fixed effect diperoleh hasil R-square sebesar 0.721370. jadi dapat dilihat jika variabel independen yaitu LogMudharabah, LogMusyarakah, LogMurabaha, FDR, BOPO, LogAsset dan pertumbuhan ekonomi (GDP) mampu menjelaskan variabel dependen Nonperforming financing sebesar 72,13\%. Sedangkan sisanya yaitu $27.87 \%$ dijelaskan oleh variabel yang tidak diteliti dalam penelitian ini.

\section{b. Uji Signifikansi Model (F statistik)}

Selain melakukan evaluasi hasil regresi secara individual, dalam analisis regresi juga diperlukan untuk melakukan evaluasi hasil regresi semua variabel independen terhadap variabel dependen secara keseluruhan dengan uji $\mathrm{F}^{2}$. Hipotesis penelitian ini dengan uji $\mathrm{F}^{2}$ adalah:

$\mathrm{H}_{0}: \beta_{0}=\beta_{1}=\beta_{2}=\beta_{3}=\beta_{4}=\beta_{5}=\beta_{6}=\beta_{7}=0$ secara serempak variabel independen tidak berpengaruh.

$\mathrm{H}_{\mathrm{a}}: \beta_{0} \neq \beta_{1} \quad \AA_{2} \quad \AA_{3} \quad \AA_{4} \quad \AA_{5} \quad \nexists_{6} \quad \AA_{7} \neq 0$ secara serempak variabel independen berpengaruh.

Hasil pengujian menggunakan Eviews menunjukkan nilai F-hitung sebesar 24.80721 dengan nilai probabilitas F-hitung sebesar 0.000000. dengan begitu dapat disimpulkan jika Fhitung lebih besar dari F-kritis (F-hitung > F-kritis) maka dengan ini kita menolah $\mathrm{H}_{0}$ dan menerima $\mathrm{H}_{\mathrm{a}}$ jika semua variabel independen yaitu Mudharabah, Musyarakah, Murabaha, 
FDR, BOPO, Asset dan GDP secara serempak berpengaruh terhadap Nonperforming Financing.

\section{c. Uji Signifikan Variabel Independen (T-statistik)}

Uji t statistik digunakan untuk mengetahui signifikansi dari variabel independen terhadap variabel dependen secara parsial atau individu variabel independen. Berikut uji signifikasi setiap variabel dalam penelitian ini.

\section{d. Uji Variabel Mudharabah Terhadap Nonperforming Financing (NPF)}

Berdasarkan hasil uji regresi data panel diperoleh nilai $t$-statistik variabel Mudharabah sebesar -4.217579 dengan probabilitas sebesar 0.0000 dengan $\alpha$ 5\%. Dalam menentukan nilai $t$-kritis menggunakan persamaan:

$$
\begin{aligned}
& \text { df }=n-k \\
& \text { df }=89-7 \\
& \text { df }=82
\end{aligned}
$$

Berdasarkan tabel $t$-kritis dengan $\mathrm{df}=82$ dan $\alpha 5 \%$ maka diperoleh nilai $t$-kritis sebesar 1.66365. maka dengan ini dapat disimpulkan jika t-hitung lebih kecil ( $t$-hitung $<t$-kritis) sehingga menolak $\mathrm{H}_{0}$ yang artinya variabel Mudharabah berhubungan negatif dan signifikan terhadap variabel dependen Nonperforming Financing. Dari hasil regresi dapat dilihat jika nilai $t$-hitung dari variabel Mudharabah bernilai negatif (-4.217579) ini bermakna variabel Mudharabah berhubungan negatif dengan variabel Nonperforming Financing. Nilai koefisien $t$-hitung sebesar -1.082479 . nilai koefisien yang negatif bermakna adanya hubungan yang tidak searah, yakni jika pembiayaan Mudharabah naik sebesar satu rupiah maka terjadi penurunan Nonperforming Financing sebesar -1.082479.

Hubungan yang tidak searah antara Mudharabah terhadap Musyarakah ini tentu berbeda dengan teori dan konsep serta hasil penelitian sebelumnya, Jika kontrak PLS salah satunya Mudharabah adalah kontrak keuangan Islam dengan tingkat risiko yang tinggi ${ }^{26}$. Hal ini disebabkan karena BPRS yang menjadi objek dalam penelitian ini masih tergolong sebagai BPRS dengan ukuran kecil. Selain itu juga karena banyak dari BPRS yang tidak menyalurkan pembiayaan dengan kontrak Mudharabah, hal ini tidak terlepas dari stigma kontrak PLS seperti Mudharabah dan Musyarakah dapat menghasilkan moral hazard, asimetris informasi dan biaya yang lebih besar ${ }^{27}$. Hubungan yang terbalik antara Mudharabah terhadap NPF ini relevan dengan penelitian yang dilakukan oleh ${ }^{28}$ yang menemukan jika pembiayaan dengan PLS berdampak positif terhadap NPF, namun pembiayaan PLS lebih berdampak terhadap NPF pada bank dengan skala besar dibanding dengan dampak PLS terhadap NPF pada bank dengan skala kecil. Selain itu juga karena porsi pembiayaan dengan kontrak Mudharabah masih sangat kecil jika dibanding dengan pembiayaan dengan kontrak lain. Hasil ini sesuai

${ }^{26}$ Warninda, Ekaputra, and Rokhim, "Do Mudarabah and Musharakah Financing Impact Islamic Bank Credit Risk Differently?"

${ }^{27}$ Mongi Lassoued, "Comparative Study on Credit Risk in Islamic Banking Institutions: The Case of Malaysia," Quarterly Review of Economics and Finance 70 (2018): 267-278.

28 Agus Widarjono, M. B.Hendrie Anto, and Faaza Fakhrunnas, "Financing Risk in Indonesian Islamic Rural Banks: Do Financing Products Matter?," Journal of Asian Finance, Economics and Business 7, no. 9 (2020): 305-314. 
dengan penelitian yang dilakukan oleh ${ }^{29}$. Besar dan kecil-nya jumlah pembiayaan dengan kontrak apapun akan berpengaruh signifikan terhadap risiko yang dihadapi oleh bank. Hal ini sesuai dengan penelitian yang dilakukan oleh ${ }^{30}$ dan ${ }^{31}$ bahwa jenis pinjaman yang tidak memiliki pengaruh yang signifikan terhadap risiko bank adalah pinjaman dengan porsi terkecil.

\section{Simpulan}

Dari hasil dan pembahasan diatas dapat disimpulkan bahwa variable Mudharabah berhubungan negative dan signifikan terhadap Non Performing Financing. Sehingga penelitian ini dapat membantah jika Kontrak Mudharabah dapat meningkatkan resiko kredit macet.

Disarankan bagi stakeholder untuk meningkatkan pembiayaan berbasis Mudharabah, sebab dengan dengan begitu dapat meringankan gairah nasabah dalam mengembangkan bisnisnya sebab potensi profit mitra justru lebih besar. Sumbangsih pertumbuhan ekonomi dari sector perbankan Syariah juga lebih maksimal. Bagi peneliti selanjutnya yang tertarik dengan isu yang sama disarankan agar lebih memperbanyak jenis pembiayaan, jumlah sampel.

\section{Daftar Pustaka}

Akbar, Dinul Alfian. "Inflasi, Gross Domesctic Product (Gdp), Capital Adequacy Ratio (Car), Dan Finance To Deposit Ratio (Fdr) Terhadap Non Performing Financing (Npf) Pada Bank Umum Syariah Di Indonesia." I-Economics 2, no. 2 (2016): 19-37.

Ariffin, Noraini Mohd, Simon Archer, and Rifaat Ahmed Abdel Karim. "Risks in Islamic Banks: Evidence from Empirical Research.” Journal of Banking Regulation 10, no. 2 (2009): 153-163.

Breusch, T. S., and A. R. Pagan. "The Lagrange Multiplier Test and Its Applications to Model Specification in Econometrics.” The Review of Economic Studies 47, no. 1 (1980): 239.

Čihák, Martin, and Heiko Hesse. "Islamic Banks and Financial Stability: An Empirical Analysis." Journal of Financial Services Research 38, no. 2 (2010): 95-113.

Dar, Humayon a, and John R Presley. "Lack of Profit Loss Sharing in Islamic Banking : Management and Control Imbalances." International Journal of Islamic Financial Services 2, no. 00 (2000): 9-12.

Effendi, Jaenal, Usy Thiarany, and Tita Nursyamsiah. "Factors Influencing Non-Performing Financing (NPF) at Sharia Banking." Walisongo: Jurnal Penelitian Sosial Keagamaan 25, no. 1 (2017): 109.

Hafsa Orhan Astrom, Zeyneb. "Credit Risk Management Pertaining to Profit and Loss Sharing Instruments in Islamic Banking." Journal of Financial Reporting and Accounting 11, no. 1 (2013): 80-91.

\footnotetext{
${ }^{29}$ Warninda, Ekaputra, and Rokhim, "Do Mudarabah and Musharakah Financing Impact Islamic Bank Credit Risk Differently?"

30 Gabriel Jiménez and Jesús Saurina, "Collateral, Type of Lender and Relationship Banking as Determinants of Credit Risk," Journal of Banking and Finance 28, no. 9 (2004): 2191-2212.

31 Steve Mercieca, Klaus Schaeck, and Simon Wolfe, "Small European Banks: Benefits from Diversification?," Journal of Banking and Finance 31, no. 7 (2007): 1975-1998.
} 
Hirukawa, Masayuki. “Specification Testing” 46, no. 6 (2018): 73-101.

Jiménez, Gabriel, and Jesús Saurina. "Collateral, Type of Lender and Relationship Banking as Determinants of Credit Risk." Journal of Banking and Finance 28, no. 9 (2004): 2191-2212.

Lassoued, Mongi. "Comparative Study on Credit Risk in Islamic Banking Institutions: The Case of Malaysia." Quarterly Review of Economics and Finance 70 (2018): 267278.

Louhichi, Awatef, and Younes Boujelbene. "Credit Risk, Managerial Behaviour and Macroeconomic Equilibrium within Dual Banking Systems: Interest-Free vs. Interest-Based Banking Industries." Research in International Business and Finance 38 (2016): 104-121.

Mercieca, Steve, Klaus Schaeck, and Simon Wolfe. "Small European Banks: Benefits from Diversification?” Journal of Banking and Finance 31, no. 7 (2007): 1975-1998.

Mirakhor, Abbas, and Iqbal Zaidi. "Profit-and-Loss Sharing Contracts in Islamic Finance." Handbook of Islamic Banking m (2007): 49-63.

Mutamimah, and siti nur zaidah Chasanah. "Analisis Eksternal Dan Internal Dalam Menentukan." jurnal bisnis dan ekonomi (JBE) 19, no. 1 (2012): 49-64.

OJK, Tim. "Standar Produk Mudharabah" (2017): 1-292.

Osman, Hamdan Bin. "Pengaruh Pembiayaan Mudharabah Dan Musyarakah Terhadap Non Performing Financing (NPF).” Artikel Ilmiah (2013).

Popita, Mares Suci Ana. "Analisis Penyebab Terjadinya Non Performing Financing Pada Bank Umum Syariah Di Indonesia.” Accounting Analysis Journal 2, no. 4 (2013): 404-412.

Putra, Rosyid Nur Anggara. "Karakteristik Pembiayaan Dan Non Performing Finance Perbankan Syariah 2015-2018.” MALIA: Journal of Islamic Banking and Finance 3, no. 1 (2019): 1.

Warninda, Titi Dewi, Irwan Adi Ekaputra, and Rofikoh Rokhim. "Do Mudarabah and Musharakah Financing Impact Islamic Bank Credit Risk Differently?" Research in International Business and Finance 49, no. September 2017 (2019): 166-175.

Widarjono, Agus, M. B.Hendrie Anto, and Faaza Fakhrunnas. "Financing Risk in Indonesian Islamic Rural Banks: Do Financing Products Matter?" Journal of Asian Finance, Economics and Business 7, no. 9 (2020): 305-314.

Zeineb, Ghada Ben, and Sami Mensi. "Does the PLS Paradigm Spur the Islamic Banks Vs Conventional Banks Soundness: Case of the Global Financial Crisis." Journal of Economics and Development Studies 2, no. 3 (2014): 177-192.

"Ekonometrika Pengantar Dan Aplikasinya Edisi 5 - Agus Widarjono | Shopee Indonesia." Accessed April 11, 2021. https://shopee.co.id/Ekonometrika-Pengantar-DanAplikasinya-Edisi-5-Agus-Widarjono-i.3813657.1658609173.

SNAPSHOT PERBANKAN SYARIAH INDONESIA 2020, n.d.

"Statistik Perbankan Syariah." Accessed April 11, 2021. https://www.ojk.go.id/id/kanal/syariah/data-dan-statistik/statistik-perbankan- 
syariah/default.aspx.

"Undang-Undang Nomor 21 Tahun 2008 Tentang Perbankan Syariah.” Accessed November 27, 2020. https://www.ojk.go.id/waspada-investasi/id/regulasi/Pages/UndangUndang-Nomor-21-Tahun-2008-Tentang-Perbankan-Syariah.aspx. 